\title{
Should hiding HIV status always be a crime?
}

$\mathrm{C}$ anadians living with HIV should not face jail time for keeping their medical condition from sexual partners if the risk of transmission is low or if they use condoms while having sex, civil liberties advocates say.

Criminal prosecution should be reserved for those who intentionally infect others, they add while asking the Supreme Court of Canada to define the meaning of "significant risk of harm" and compel its use as a standard in determining whether to prosecute people (using Criminal Code provisions such as aggravated sexual assault) who fail to disclose their HIV-positive status to sexual partners.

That notion of prosecuting only those who pose a significant risk to sexual partners has gradually emerged from a landmark 1998 Supreme Court ruling, $R$. v. Cuerrier, in which the court held that a failure to disclose HIV status invalidates a sexual partner's consent (http://scc.lexum.org/en/1998/1998 scr2-371/1998scr2-371.pdf). In the course of that ruling, Justice Peter Cory surmised that that the degree of risk of contracting HIV "might" be a factor in determining whether to prosecute someone who did not disclose their HIV status. But Cory did not define the level of significant risk and lower courts have subsequently used that ambiguity to undermine the concept of meaningful consent in favour of a more statistical approach in which the likelihood of HIV transmission (i.e., significant risk) is the deciding factor in charging and convicting HIV-positive people who do not disclose their status to sexual partners.

The Supreme Court is now mulling a decision on Crown appeals of two provincial appellate decisions $-R$. v. Mabior and $R$. v. $D C$ - that overturned the convictions of HIV-positive individuals on the grounds that their viral loads were such that they did not expose their sexual partners to anything like a significant risk of contracting HIV.

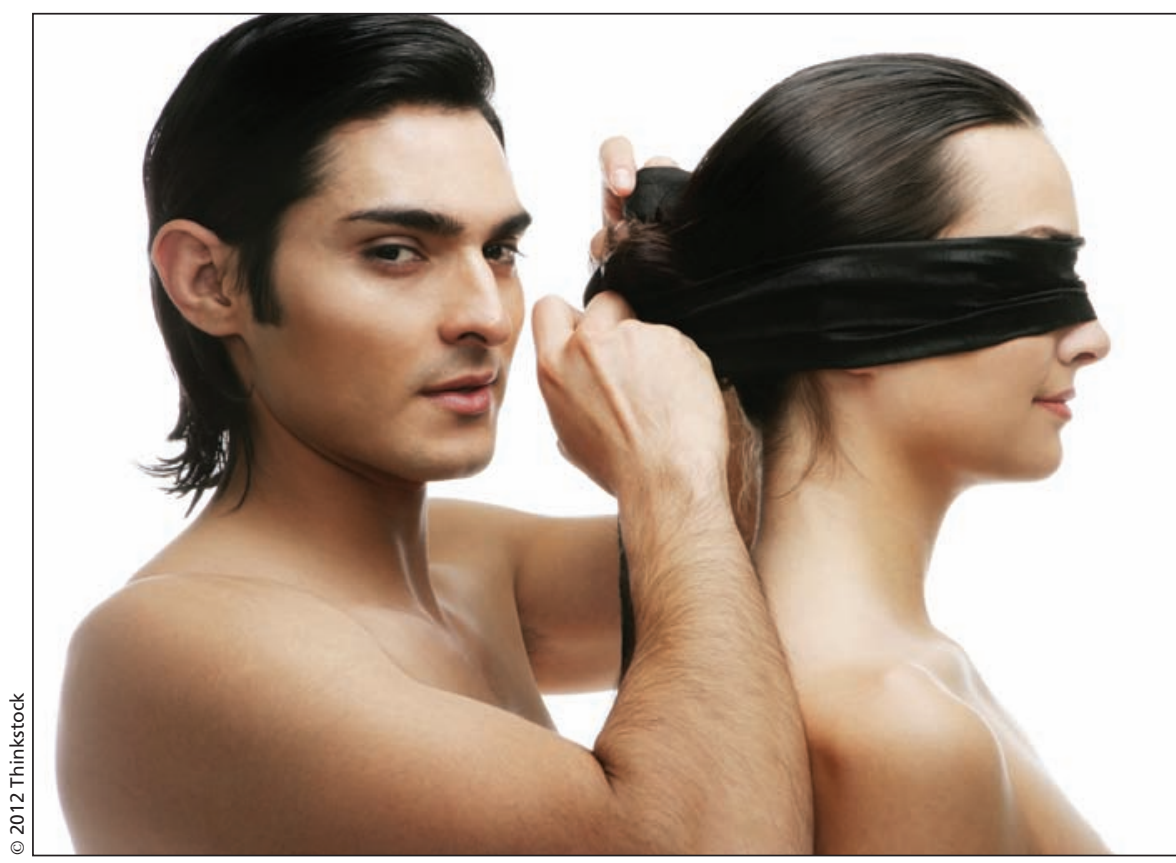

Crown prosecutors argue that criminal charges for failure to disclose HIV status are justified as informed consent cannot possibly have been granted when a person has not disclosed HIV status and left a sexual partner entirely unaware about the health risk to which they are being exposed.

The civil liberties advocates argue that significant risk is a legitimate tool in determining whether to prosecute and/or convict someone. Moreover, they argue that scientific progress has changed the nature of what constitutes significant risk.

"We are using some of the most serious offences in the Criminal Code in some of these cases. It's like cracking a nut with a sledgehammer. It's a wildly disproportionate response," says Richard Elliott, executive director of the Canadian HIV/AIDS Legal Network, an intervener in the cases. "If your goal is to protect public health, then you ought to look at the tools public health has to offer."

Crown prosecutors counter in their factums to the court that criminal charges for failure to disclose HIV status should fall under the ambit of the original test established in Cuerrier, i.e., that true consent cannot be considered as having been granted when a person has not disclosed HIV status. Moreover, they contend that the notion of significant risk was never intended to vitiate consent and never could until such point as HIV becomes a disease of the past or a vaccine is developed to completely eliminate the risk of transmission (www.scc -csc.gc.ca/factums-memoires/33976/FM 010_Appellant_Her-Majesty-the-Queen .pdf and www.scc-csc.gc.ca/factums -memoires/34094/FM010_Appelante_Sa -Majest\%C3\%A9-la-Reine_\%C3\%A9 pur\% $\% 3 \%$ A9.pdf).

But that approach, Elliott argues, would do little more than keep the floodgates open to all manner of "ridiculous" prosecution and stigmatization of people with HIV. "That floats dangerously close to criminalizing people because they have the virus, not because their conduct poses any real risk of harm to others. You have to ask yourself at a certain point, when do we start calling this what it looks like it's becoming, which is a witch hunt?"

In many of the 130 cases in which 
people have been charged with a criminal offence since the Cuerrier ruling, a condom was used during sex or the accused had an undetectable viral load, Elliott adds. "Science now tells us that the risk of transmission in such cases is so low it should not be considered legally significant."

That position is supported by the Joint United Nations Programme on HIV/AIDS, which has argued that criminal charges should be limited to intentional transmission of the disease as there is no evidence that prosecution for nonintentional transmission is an effective means of reducing HIV transmission rates (http://data.unaids.org /pub/BaseDocument/2008/20080731_jc 1513_policy_criminalization_en.pdf).

Criminalization has an "extremely ostracizing and discriminating effect on people living with HIV" and may increase spread of the virus as some people might avoid testing and other public health services such as counseling and treatment for substance abuse for fear of prosecution, says Ian Culbert, director of communications and development for the Canadian Public Health Association.

Micheal Vonn, policy director for the BC Civil Liberties Association, concurs. "If we really want to get seri- ous about making sure people are getting the care and treatment they need, we have to acknowledge this is a terrible disincentive."

Such prosecutions also undermine the public health message that it's best for individuals to take responsibility for their own protection, rather than rely on a legal obligation of HIV-positive people to disclose their status, Vonn adds. "From a public health standpoint, this is disastrous. At the risk of sounding like I'm standing here with a bonnet and crinoline on, whatever happened to safer sex?"

Culbert says that a more nuanced approach, in which the response to a failure to disclose is proportional to the health risk, offers the "least intrusive, most effective" alternative to prosecution.

Such a public health approach might be based on several levels of intervention, starting with counselling, education, surveillance and help accessing support services, such as those for substance abuse treatment, Culbert adds. The level of intervention could graduate to include the issuance of public health orders, detention in a hospital or community care facility and only thereafter, as a final resort, should it include prosecution.
That would better address the underlying reasons why people hide their HIV-positive status, Elliott says. "Is there an underlying addiction issue, for example? Is the fact she hasn't disclosed that she has HIV to her partner because he's abusive? Let's deal with those things first."

"Maybe in some cases you're just dealing with someone who's a jerk and you need to escalate things more quickly, but you can at least try those interventions which are really aimed more at preventing harm first," he adds.

Such a public health approach could also help parse out cases where the law is being used abusively by a person seeking revenge on an HIV-positive partner, Vonn says. "We see women living with HIV who tell absolutely heartbreaking stories of being in abusive relationship and being threatened, [by a partner who says:] 'If you leave me, if you don't do as I say, I will use the fact you have HIV against you'."

Some 65000 Canadians were living with HIV in 2009, according to the Public Health Agency of Canada (www .phac-aspc.gc.ca/aids-sida/publication /survreport/2009/dec/pdf/2009-Report -Rapport.pdf). — Lauren Vogel, CMAJ

CMAJ 2012. DOI:10.1503/cmaj.109-4190 